\title{
Josef Ryš (1879-1960), pedagog, mineralog, sběratel a jeho sbírka minerálů v Národním muzeu v Praze
}

\author{
Josef Ryš (1879-1960), pedagogue, mineralogist, collector and his collection of \\ minerals in the National Museum in Prague
}

\section{Helena Ulčová ${ }^{1} \&$ Dalibor Velebil ${ }^{2,}$}

\author{
${ }^{1}$ Městské muzeum Jevíčko, Komenského náměstí 167, 56943 Jevíčko; muzeumjevicko@seznam.cz \\ ${ }^{2}$ Národní muzeum, Mineralogicko-petrologické oddělení, Cirkusová 1740, 19300 Praha 9; \\ dalibor_velebil@nm.cz \\ *corresponding author
}

Ulčová H., Velebil D., 2020: Josef Ryš (1879-1960), pedagog, mineralog, sběratel a jeho sbírka minerálů v Národním muzeu v Praze. - Journal of the National Museum (Prague), Natural History Series 189: 31-48.

\begin{abstract}
Abstrakt: Josef Ryš (*1879, †1960) byl středoškolský profesor na Reálné škole v Jevíčku, významný lokální badatel - mineralog a starosta místní tělovýchovné jednoty Sokol. V letech 1909 až 1958 publikoval celkem 11 prací o geologických a mineralogických poměrech širokého okolí Jevíčka. Spolupracoval s významnými institucemi, jako je Moravské zemské muzeum v Brně, Masarykova univerzita v Brně, Univerzita Karlova v Praze a Národní muzeum v Praze. Vybudoval kvalitní sbírku českých i světových minerálů, z níž je celkem 913 kusů uloženo ve sbírce Národního muzea v Praze. Z tohoto souboru bylo 65 minerálů vybráno pro novou stálou expozici minerálů Národního muzea.
\end{abstract}

Abstract: Josef Ryš (* 1879, † 1960) was a high school professor at the Real School in Jevíčko, a prominent local researcher - mineralogist and head of the local physical education unit Sokol. Between 1909 and 1958, he published a total of 11 works on the geological and mineralogical conditions of the greater Jevíčko area. He has collaborated with important institutions, such as the Moravian Museum in Brno, Masaryk University in Brno, Charles University in Prague and the National Museum in Prague. He has built a quality collection of Czech and world minerals, of which a total of 913 pieces are stored in the collection of the National Museum in Prague. From this collection, 65 minerals were selected for the new permanent mineralogical exhibition of the National Museum.

Klíčová slova: Josef Ryš, geologie, mineralogie, boskovická brázda, Jevíčko, Moravská Třebová, Národní muzeum Praha, Morava, Česká republika

Keywords: Josef Ryš, geology, mineralogy, Boskovice Furrow, Jevíčko, Moravská Třebová, National Museum Prague, Moravia, Czech Republic

Received: May 12, 2020 | Accepted: August 10, 2020 | Published on-line: October 16, 2020 


\section{Úvod}

Pražský rodák Josef Ryš $(* 1879$, †1960) strávil většinu svého profesního života jako středoškolský pedagog v Jevíčku na severozápadní Moravě. Do širokého okolí tohoto města směřoval své intenzivní úsilí v oblasti mineralogických a geologických výzkumů. Profesor Ryš prozkoumal většinu moravských a východočeských mineralogických lokalit a publikoval řadu vlastivědných článků z geologie a mineralogie, hlavně z okolí Jevíčka (Ryš 1909, 1910, 1911, 1912, 1931a-d, 1940, 1958). Byl v kontaktu s mnoha moravskými sběrateli a intenzivně spolupracoval zejména s Moravským zemským muzeem v Brně (Tvrzník 1961), ale i dalšími institucemi; $v$ častém písemném kontaktu byl s mineralogem, profesorem Masarykovy univerzity Josefem Sekaninou (*1901, †1986). Ryš vybudoval pěknou sbírku minerálů, jejíž jádro získalo Národní muzeum v Praze. Jméno Josefa Ryše nikdy neupadlo v zapomnění, své místo dokonce našel mezi biografiemi významných geologů v Naučném geologickém

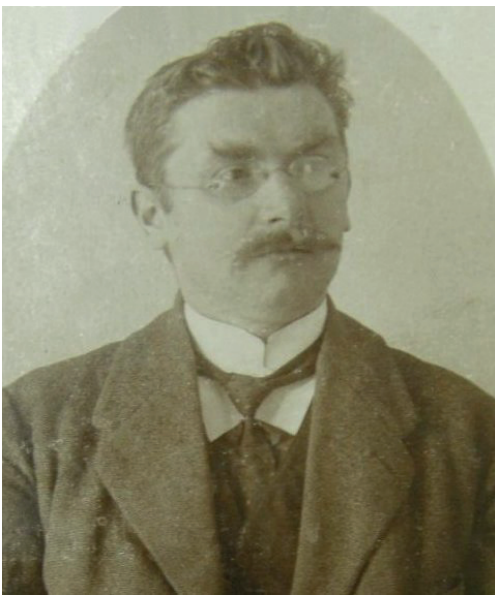

Obr. 1. Josef Ryš na portrétu z roku 1912 ve věku 33 let (členský průkaz Sokola, SOA Svitavy, fond č. 1246 Ryš Josef). slovníku (Tvrzník 1961) a ve sbírkách Vysoké školy chemicko-technologické v Praze visí dodnes jeho portrét. Ryš vedl př́kladný, pestrý život zasvěcený především vzdělávání a výchově mládeže, z níž se poté stávala intelektuální a manažerská elita společnosti; nemálo času věnoval své zálibě v geologii a mineralogii a i v těchto oborech přispíval k našemu poznání. Není proto na škodu si osobnost Josefa Ryše připomínat i nadále, v tomto textu i v souvislosti s jeho odkazem v podobě jeho sbírky minerálů.

\section{Životní data, profesní a veřejné aktivity}

Josef Ryš se narodil 6. ledna 1879 v Praze, kde v roce 1897 absolvoval Reálné gymnázium v Křemencově ulici (Státní oblastní archiv Svitavy, fond 1246 Ryš Josef). Poté vystudoval v letech 1897-1901 př́rodní vědy na Filosofické fakultě Karlovy university, kde byl žákem mineraloga profesora Karla Vrby $(* 1845, \uparrow 1922)$. Ve stejné době studovali na Karlově universitě také pozdější významní mineralogové: akademik Josef Kratochvíl (*1878, †1958), autor osmidílného díla Topografická mineralogie Čech, profesor František Slavík (*1876, †1957), mj. rektor Karlovy university, a profesor Vojtěch Rosický $(* 1880, \uparrow 1942)$, zakladatel mineralo-

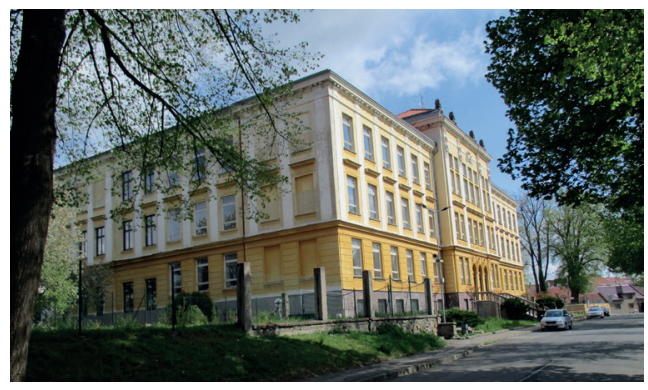

Obr. 2. Budova Gymnázia v Jevíčku (dříve reálná škola) z roku 1899, v níž Josef Ryš v letech 1903-1939 a pak ještě v letech 1945-1948 učil. Foto: H. Ulčová, 2020. gicko-petrografického ústavu brněnské Masarykovy university (Kruta 1960). Po absolutoriu univerzity, kterou zakončil státní zkouškou z prŕrodopisu, matematiky a fyziky, učil Josef Ryš od roku 1901 po dva školní roky jako zatímní profesor (suplent) na c. k. státní české reálné škole na Starém Městě v Praze. Roku 1903 byl výnosem Moravského zemského soudu jmenován tzv. skutečným učitelem a od toho roku až do svého penzionování v roce 1939 působil jako profesor na Reálné škole v Jevíčku. V Jevíčku se Ryš oženil s dcerou místního pekaře Aloisií 
Janouškovou (*1885, †1960), s níž měl dvě děti, Jaroslavu (*1913, †2009) a Přemysla $\left({ }^{*} 1919, \dagger 2005\right)$.

$\mathrm{V}$ roce 1912 byl Ryš usnesením c. k. ministerstva kultury a vyučování přeřazen do VIII. hodností třídy (Kronika školy, školní rok 1912/13). Do relativně poklidného a úspěšného osobního i profesního života Josefa Ryše zasáhla první světová válka. Školní rok 1914/15 byl ukončen předčasnými maturitami studentů posledního, sedmého ročníku, kteří byly vzápětí odvedeni do armády. Celkem bylo během války na frontu odveleno 42 absolventů školy, z nichž 21 padlo (Ryš 1937). Ryš byl nejprve na dobu neurčitou zproštěn vojenské služby, ale dne 26. 6. 1917 byl povolán $\mathrm{k}$ lékařské prohlídce do Šumperka, kde byl uznán způsobilým vojenské služby a do 48 hodin narukoval do armády (Kronika školy, školní rok 1916/17). O jeho účasti ve válce není známo nic bližšího, podle fotografií dochovaných $\mathrm{v}$ jeho pozůstalosti se zdá, že bojoval na frontách na Balkáně a v Itálii. Nicméně

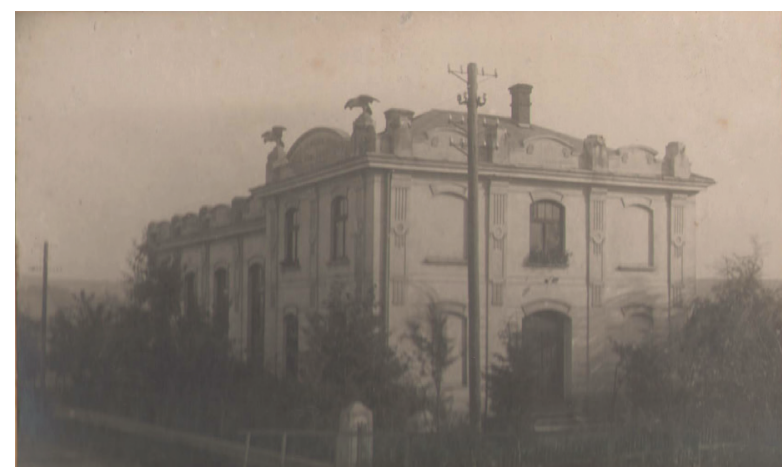

Obr. 3. Budova sokolovny v Jevíčku na staré fotografii. Archiv Městského úřadu Jevíčko.

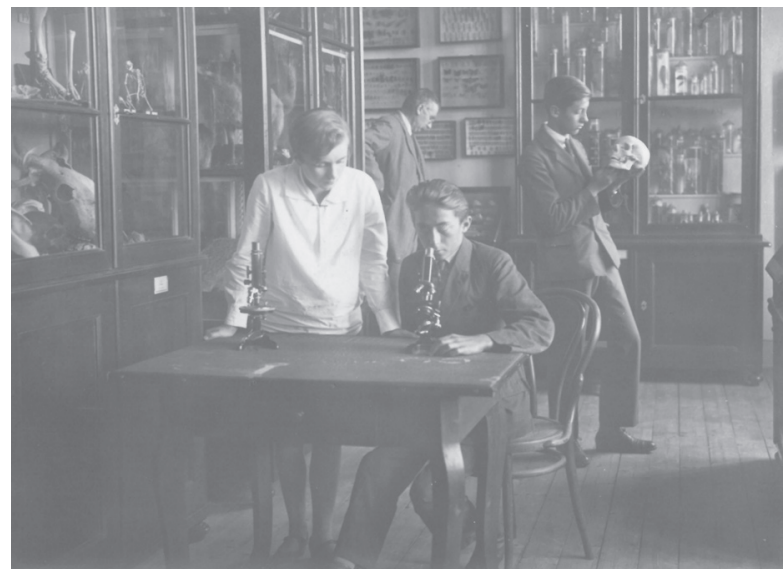

Obr. 4. Ryšův přírodopisný kabinet v budově Reálné školy v Jevíčku na fotografii z roku 1927. Foto: J. Ryš. Archiv Muzea v Jevíčku. z války se vrátil nezraněn a dál působil jako učitel v Jevíčku.

Josef Ryš se aktivně podílel na veřejném životě v Jevíčku. Byl členem zdejší Tělocvičné jednoty Sokol, podle jeho členského průkazu nejpozději od roku 1908, spíše ale ještě dříve. Bývalý Ryšův kolega - učitel jevíčské reálky Josef Kraus (v Jevíčku cca v letech 1907 až 1908, po roce 1945 na presidiu zemské školní rady) v dopise Ryšovi z 8. 9.1947 vzpomínal: „Dobře si pamatuji, jak jste mne mezi sebe prijímali, Ty a dr. Jakub a Drbal, jednou z prvých Tvých otázek bylo: na jaký nástroj umíš hrát? (...) Vzpomínám na své začátky sokolské: stal jsem se brzo po nastoupení jednatelem a dobře se pamatuji, jak jsem po jakési neshodě ve výboru se $s$ důvěrou obrátil na Tebe, abys se ujal vedení jednoty." (SOA Svitavy, fond 1246 Ryš Josef). (Pozn.: Vojtěch Jakub profesorem Reálné školy v Jevíčku v letech 1901-1907, Vladimír Drbal v letech 1901-1908)

Z blahopřání, uveřejněném 17. 2. 1939 v místním tisku k Ryšovým 60. narozeninám, se dozvídáme, že ještě před 1. světovou válkou se Ryš skutečně stal starostou místního Sokola $\mathrm{a}$ „V době státního převratu (zřejmě v říjnu 1918) zahajoval na náměstí v Jevíčku v sokolském kroji první manifestační tábor svobodných a svorných občanů Malé Hané." Jako starosta Sokola se Ryš v době popřevratové zúčastnil založení okresního národního výboru, který 


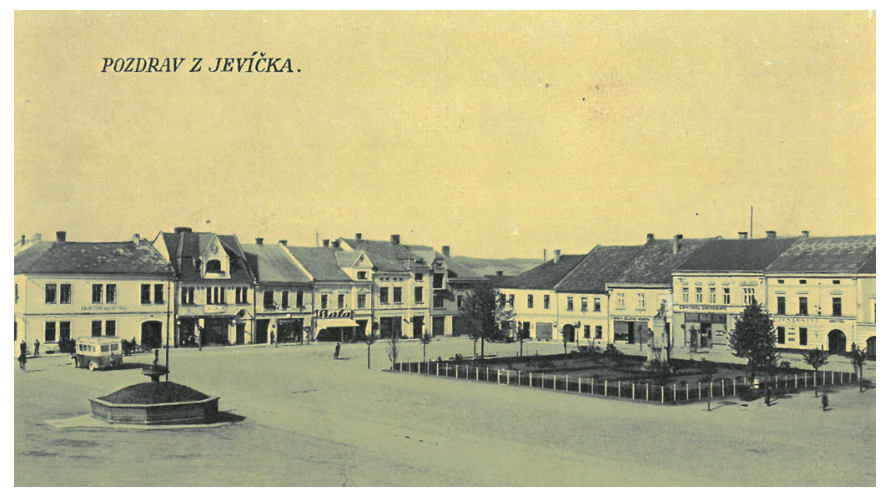

Obr. 5. Náměstí v Jevíčku na staré pohlednici. Nalevo od středu snímku je Ryšův dům s prodejnou Bat’a.

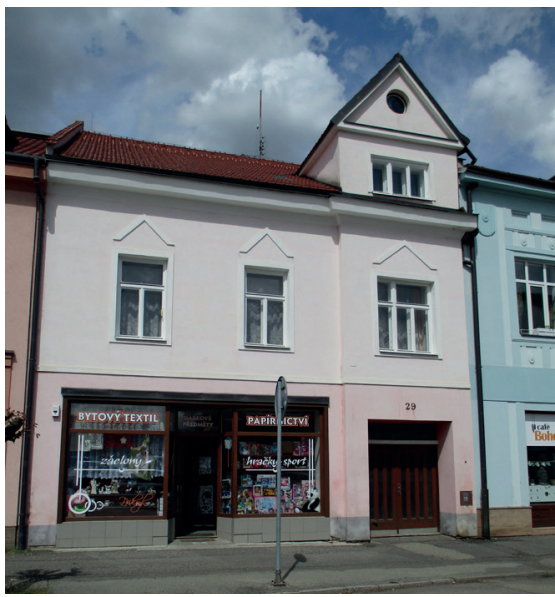

Obr. 6. Dům na Palackého náměstí v Jevíčku, v němž Josef Ryš s manželkou Aloisií, rozenou Janouškovou, a dětmi Jaroslavou a Přemyslem bydlel; původně dům pekařské rodiny Janouškových; v přízemí domu bývalo pekařství a později, přibližně v letech 1936-1970 prodejna obuvi Bat’a. Za domem se nacházela pekárna, v níž později Ryš uchovával své mineralogické a geologické sbírky. Foto: H. Ulčová, 2020. fond 1246 Ryš Josef). převzal funkci okresního hejtmanství moravsko-třebovského (Ryš 1937). V narozeninovém blahopřání představitelé Sokola Ryšovi poděkovali za „obětavou práci organizační, hospodářskou a osvětovou“.

Do doby těsně před 1. světovou válkou jsou datovány dopisy Ryšova př́tele $\mathrm{z}$ dob studií, hudebního kritika, muzikologa, estetika, skladatele a vysokoškolského pedagoga Otakara Zicha $\left({ }^{*} 1879\right.$, †1934). Zich v dopisech zmiňuje Ryšovo předsednictví Sokola (před rokem 1914), narození Ryšovy dcery a peripetie okolo komponování Zichovy opery s názvem Vina. Vyplývá z nich také, že Otakar Zich byl ve hmotné nouzi a Ryš mu opakovaně zasílal peníze, nicméně není zcela jasné, jestli šlo o finanční dary nebo splátky nějaké dřívější pohledávky (SOA Svitavy,

Ze školní kroniky vyplývá, že Josef Ryš hrál na violu a jako hudebník se pravidelně účastnil školních akademií. Kromě výuky byl pověřen také správou studentského internátu a přidělováním jídla chudým studentům. Věnoval se fotografování; na svých fotografiích zachytil např́klad studenty $\mathrm{v}$ př́rodopisném kabinetu nebo skupiny cvičenců ve staré tělocvičně u zámečku a cvičení v provizorních prostorách. Ve stavebním archivu města Jevíčka jsou uchovány Ryšovy posudky k plánovaným novostavbám rodinných domů, včetně požadavků na zachování stávající zeleně. Stanoviska k této problematice si od něj patrně vyžádali představitelé města jako od respektované, $v$ prrírodních vědách vzdělané osobnosti.

Z medailonu od Oldřicha Bubeníka, věnovaného J. Ryšovi a uveřejněného ve sborníku k 70 letům střední školy v Jevíčku, se o Ryšovi dozvídáme: „Nejenže výborně učil, ale také vychovával, byl př́sný, ale přesto jen on měl př́zvisko „táta“ a tento název si plně zasloužil vším svým působením mezi studující mládeží. Patřil též $k$ nejvýraznějším pokrokovým a vlasteneckým postavám společenským a kulturním na místě tak národně exponovaném, jako bylo Jevíčko. O jeho lásce k mládeži svědčí i to, že vedl dlouhá desetiletí loutkové divadlo jako obětavý reditel, dramaturg, režisér a herec v jedné osobě." (Bubeník 1967).

Zdá se, že svými žáky byl Josef Ryš respektován a těšil se i určité oblibě. Jan Suchomel z Jevíčka vzpomínal na Ryše - pedagoga takto: „Byl jsem jeho žákem na zdejší reálce v minera- 


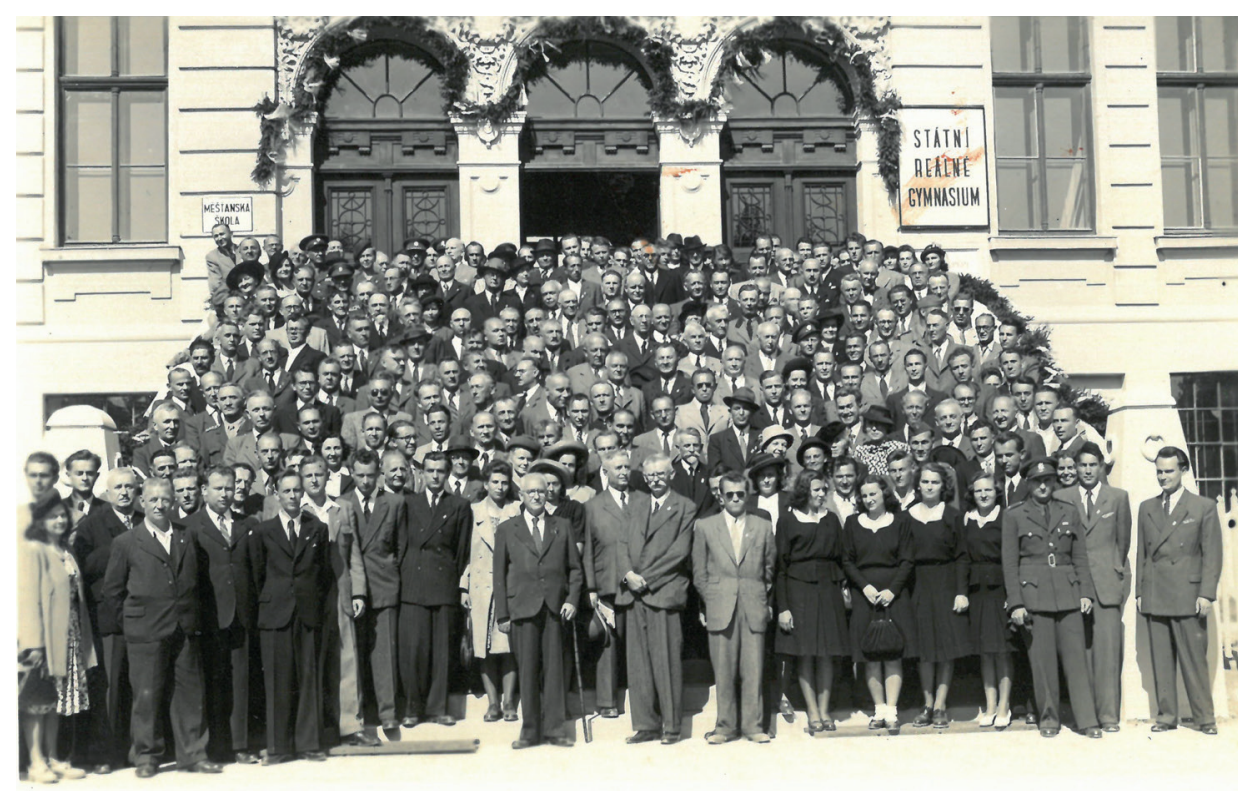

Obr. 7. Hromadná fotografie pořízená před jevíčským gymnáziem u příležitosti výročí školy (rok 1947?). Josef Ryš dole uprostřed (muž s knírem a brýlemi).

logii a zeměpisu. Jeho přednášky byly plné zajímavosti a kouzla, jeho zkoušky byly náročné a př́sné." (Suchomel in Skořepa 2011). Další z Ryšových žáků Jaromír Korčák (*1895, †1989), později významný geograf, vyjádřil v roce $1922 \mathrm{v}$ dopise Ryšovi poděkování a vděčnost za školní vzdělání a vzpomínal: „Vážený pane profesore! Přehlížeje po ukončení vývoj svého školského vzdělání, cítím povinnost, ř́ci svým učitelům, že jejich žáci jsou jim vděční. (...) Nezapomněl jsem nikdy na Vaše hodiny přírodopisu ve vyšších třídách. Především: základy fyziologie rostlin, theorie vývojové; geologické poznámky při vycházce na Červený kopec (zvláště Váš výklad lamarkismu a darwinismu zanechal ve mně ohromný dojem, představuji si dodnes, kde jste tehdy stál, jaké jste měl šaty) (...) Velká většina kolegů vstupovala na vysokou školu majíc o těchto věcech predstavy mnohem neurčitější než my z Jevíčka, hovořili i moji spolužáci." (SOA Svitavy, fond 1246 Ryš Josef). V roce 1934 byl Josef Ryš pozván Emanuelem Sedláčkem, zemským vrchním účetním radou, správcem zemské nemocnice v Brně a absolventem reálky v Jevíčku na sraz prvních absolventů školy z roku 1904 (SOA Svitavy,

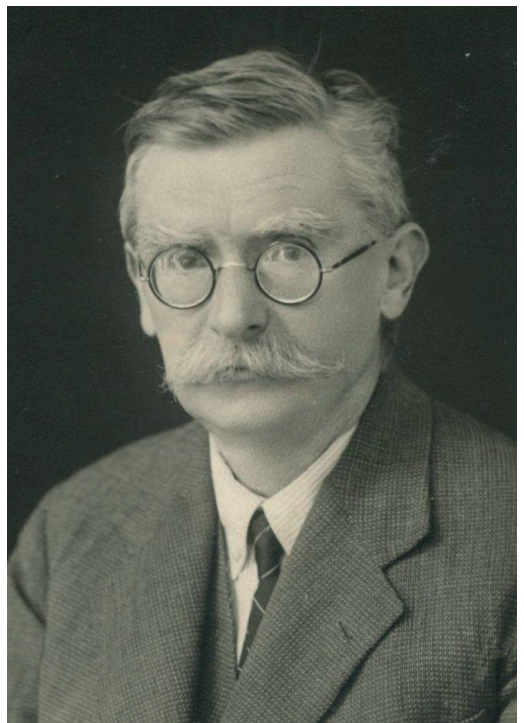

Obr. 8. Josef Ryš na portrétu z roku 1950 ve věku 71 let. Archiv Ústavu geologie a paleontologie Přírodovědecké fakulty Univerzity Karlovy. fond 1246 Ryš Josef).

U příležitosti 40. výročí založení Reálné školy v Jevíčku (založena 1897) napsal v roce 1937 Josef Ryš rozsáhlý šestnáctistránkový text, který vyšel v tištěné podobě. Je to z velké části přepis projevu ředitele školy Klimenta Ambrose a projevu J. Ryše, pronesených na 


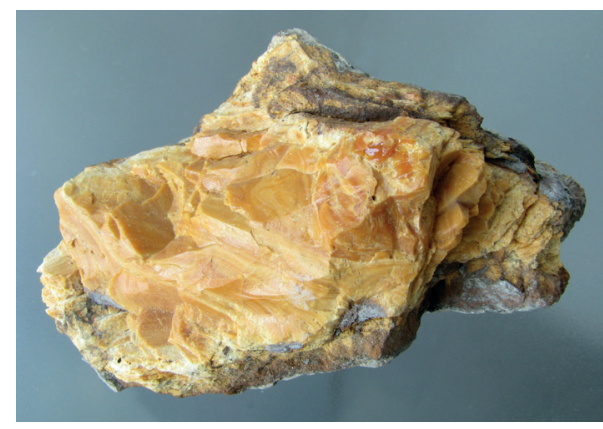

Obr. 9. Valchovit, Březina, zsz. od Jevíčka, velikost vzorku $9 \times 5$ cm (Národní muzeum P1N 47852, ex coll. J. Ryš). Foto: D. Velebil.

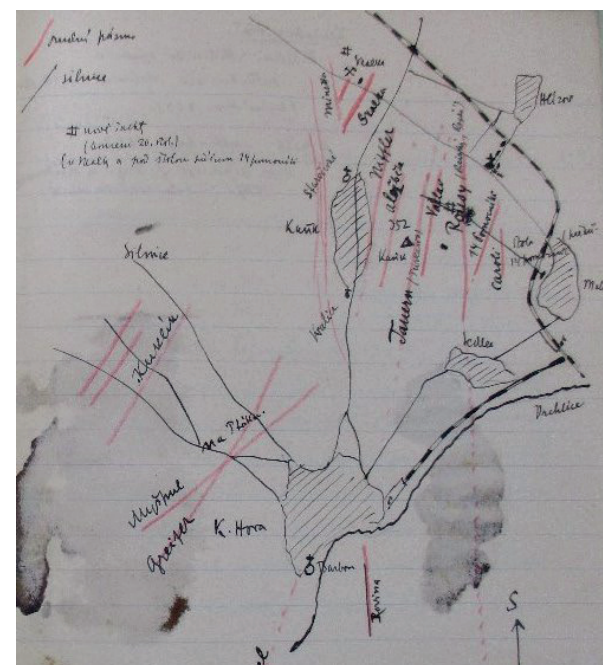

Obr. 10. Náčrtek kutnohorského rudního revíru v zápisníku Josefa Ryše (SOA Svitavy, fond 1246 Ryš Josef; sešit „Výpisky 1933“). slavnostním shromáždění v aule školy během oslav výročí. Ryš zahájil svoji řeč takto: „Dovolte mi, abych především projevil opravdové potěšení a nelíčenou radost, vida tu shromážděno tolik známých milých tvárrí, bývalých svých žákủ, žákyň a kolegů, s nimiž jsme v této budově prožívali po řadu let chvíle veselé i mrzuté, št'astné i chmurné. (...) A jistě že vzpomínky na studentský život, na dobu bujaré mladosti jsou ty nejkrášnější! Víte, na tu dřinu, obavy a zase radost z úspěchu, na kamarádskou družnost a mladé prátelství, na ty nespočetné taškařiny a povedené kousky, $s$ neutuchající oblibou každou generaci prováděné, i na zábavy, divadla, hudbu a ostatní všechnu tradiční, školní i mimoškolní činnost studentskou!“ Dále Ryš ve svém projevu podrobně rekapituloval období vzniku reálky a jejích počátků, zaujme zejména silně vlastenecký a protiněmecký tón jeho řeči (Ryš 1937).

Od školního roku 1936/37 se reálná škola transformovala na reálné gymnásium (státní československé reálné gymnasium) (Ryš 1937). Do penze odešel státní profesor Josef Ryš na vlastní žádost v únoru 1939, tedy po dovršení 60 let věku. Ministerstvo školství a národní osvěty mu vyslovilo poděkování a uznání za jeho dlouholeté a svědomité působení ve školní službě (Kronika školy, školní rok 1938/39). Podle krátké zprávy v místním tisku dorazila na konci školního roku, v červnu 1939, za státním profesorem Josefem Ryšem do jeho bytu deputace s kyticí růží a jménem školy a žactva mu poděkovala za jeho dlouholeté působení ve škole (SOA Svitavy, fond 1246 Ryš Josef).

Na Reálném gymnáziu v Jevíčku (v letech 1941-1945 bylo protektorátními úřady uzavřeno; Skořepa 2011), vypomáhal státní profesor ve výslužbě Josef Ryš při správě školy a při výuce ještě v letech 1945-1948 (Krut’a 1960). Správy školy se Josef Ryš ujal hned po skončení války s jejím opětovným otevřením. Mimo jiné obnovil školní sbírku minerálů, kterou v období mezi válkami vybudoval, a která byla v době uzavření gymnázia do značné míry rozchvácena (Továrek 1958). Ke dni 1. 12. 1945 se správy ústavu vzdal, ale s výukou vypomáhal ještě ve školním roce 1947/48. Poté pro vysoké stáŕí a zhoršení zdravotního stavu po prodělané chřipce přestal i s výukou (Kronika školy, školní rok 1945 a 1947/48). K tomu je ve školní kronice uvedeno následující: „Ústav ztrácí v něm výborného, dlouholetého učitele a vychovatele, na kterého vzpomíná mnoho jeho žáků. Za vykonanou práci zasluhuje mnoho díků všech a dlouhý, klidný odpočinek."

Z Ryšovy korespondence z června až prosince 1959 vyplývá, že na sklonku života se snažil o vydání svého vlastivědného rukopisu s pracovním názvem Malá Haná, ve formátu brožury. O vydání nejprve žádal Městský národní výbor v Jevíčku a později opakovaně Okresní národní výbor v Moravské Třebové a tiskárnu Grafia n. p. v Moravské Třebové. Byl opakovaně 
odmítán, nejprve s tím, že v textu chybí „sociálně politické zabarvení“ (Ryš rukopis doplnil) a později proto, že na vydání nejsou peníze. K vydání brožury nakonec nikdy nedošlo (SOA Svitavy, fond 1246 Ryš Josef).

Potomci Josefa Ryše se rovněž uplatnili jako pedagogové a badatelé. Jeho dcera Jaroslava Ryšová, provdaná Vrbková (*1913, †2009), učitelka na základní škole, měla tři děti: Jana (*1942, †2017), Danu a Dušana (*1947, †2019). Vnučka Josefa Ryše, Dana Vrbková, vzpomínala $v$ roce 2018 na svého dědečka jako na člověka vlídného a sečtělého, který vlastnil rozsáhlou knihovnu obsahující publikace nejen odborné, ale i beletrii rozmanitých žánrů, včetně dobrodružných knížek Karla Maye. Ty Josef Ryš své vnučce ochotně a pravidelně půjčoval

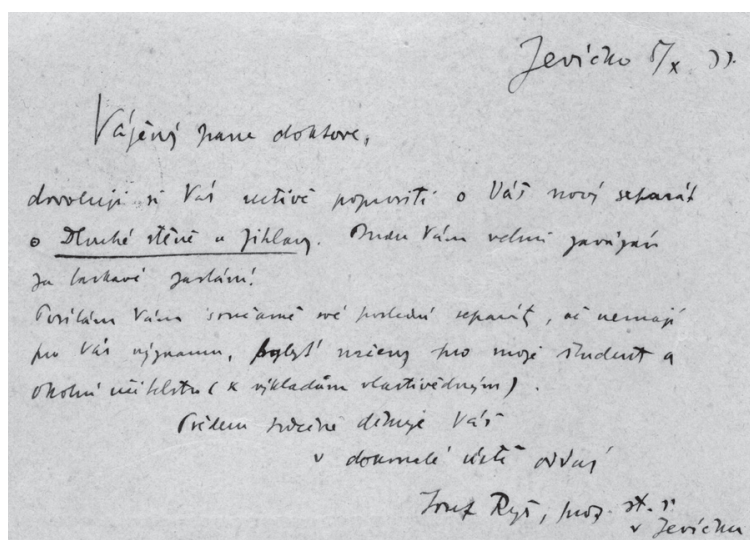

Obr. 11. Korespondenční lístek zaslaný 5. 10. 1933 Josefem Ryšem mineralogovi Josefu Sekaninovi. Soukr. Archiv: L. Kráčmara. (D. Vrbková 2018, MS - osobní vzpomínka, 14. 7. 2018). Vnuk

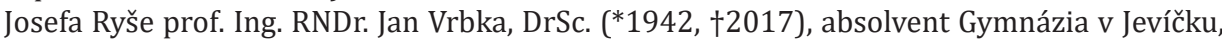
byl v letech 2000-2006 rektorem Vysokého učení technického v Brně.

Syn Josefa Ryše prof. Dr. tech. Ing. Přemysl Ryš (*1919, †2005), absolvent Gymnázia v Jevíčku a České vysoké školy technické v Brně (titul Ing. 1946) absolvoval úspěšnou vědeckou kariéru v oboru fyzikální metalurgie; v roce 1960 se stal členem korespondentem Československé akademie věd, v roce 1961 získal pedagogický titul profesora, od roku 1963 byl ředitelem Ústavu fyzikální metalurgie ČSAV v Brně, v roce 1977 získal titul akademika, v roce 1979 získal Řád práce a v roce 1985 se stal Hrdinou socialistické práce. S manželkou Helenou, rozenou Effenbergovou (*1926), měl syna Pavla Ryše, který vystudoval práva (akademický titul JUDr.) a stal se advokátem.

\section{Badatelská, sběratelská a publikační činnost}

Od svého příchodu do Jevíčka se Josef Ryš zajímal o geologickou stavbu a mineralogické poměry blízkého i širokého okolí tohoto města (Kruta 1960). Mnoho vzorků ze svých sběrných cest, uskutečněných do roku 1939, daroval či vyměnil s Př́ŕrodovědným muzeem V. F. Hlaváče v Lázních Bělohradě (zde muzeum existovalo v letech 1922-1939; Šubr, nedatováno). Po roce 1933 dával některé vzorky ze svých sběrů muzeu Zemědělského ústavu pro kulturní a hospodářské povznesení severovýchodních Čech v Hradci Králové. Sbírky tohoto ústavu (a také sbírky Hlaváčova muzea) se posléze staly součástí sbírek Muzea východních Čech v Hradci Králové, kde jsou Ryšovy kameny dodnes k dohledání, včetně jeho původních etiket. Jsou mezi nimi např́klad opály z různých nalezišt’ sbírané v průběhu roku 1932, dále wavellity z Cerhovic, vzorky valchovitů či ukázky lupků z dnes již zaniklých dolů v okolí Moravské Třebové (L. Rejl, nedatováno, MS In: archiv osobností-sběratelů, mineralogicko-petrologické oddělení Národní muzea, složka Ryš Josef).

Jak vyplývá z korespondence, dochované ve Státním oblastním archivu Svitavy (fond 1246), udržoval Ryš písemný styk nejen s českými geology, mineralogy a sběrateli, ale i se zahraničím. Na adresu jeho bydliště (Palackého náměstí $2 \mathrm{v}$ Jevíčku - dům po rodičích Ryšovy manželky Aloisie) docházely pozvánky na světové geologické kongresy či nabídky geologické 


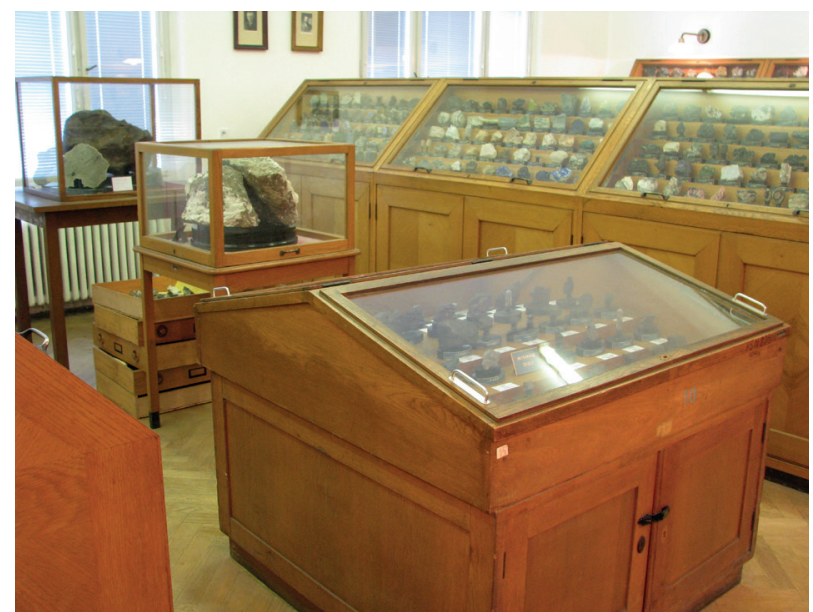

Obr. 12. Sbírka minerálů Vysoké školy chemicko-technologické v Praze. Foto: D. Velebil, 2007. literatury (Skořepa 2011). Mezi sběrateli, od nichž minerály získával a s nimiž vyměňoval, byli např́iklad Petr Vystrčil, František Stejskal, Bohumil Iran, Vilém Gross, Josef Zeman, V. Vojtěch, dále jména jako Kaláb, Polešna, Patejdl a další (SOA Svitavy, fond č. 1246 Ryš Josef). Např́íklad v roce 1935 sděluje Ryš sběrateli Vilému Grossovi z Oslavan, že u něj byl učitel Kaláb z Nové Vsi, a že se těší na zásilku nerostů z Nové Vsi a z uhelného území. Ryš mu nabízí démantoid z Dobšiné, zeolity od České Lípy, acháty a chalcedony z Kozákova, cínovec

$\mathrm{s}$ wolframitem z Cínovce, tridymit a cristobalit v andesitu, krystaly mléčného křemene od Horšovského Týna, velké desky štěpného vápence $\mathrm{z}$ Rudice, chlorit velkolupenný od Sobotína a další (M. Bohatý, soukromý archiv).

Josef Ryš publikoval několik vlastivědných prací určených především studentům a učitelům, tematicky zaměřených na geologii a mineralogii. Stěžejním dílem Ryšovy publikační činnosti je třicetistránková př́ručka Nerostné bohatství politického okresu moravsko-třebovského a jeho využití z roku 1958, v níž si autor všímá nejen mineralogických poměrů oblasti, ale i těžby a zpracování nerostných surovin. Publikace je opatřena přiloženou geologickou mapkou. V článku z roku 1931 o cenných nerostech v okolí Jevíčka a o dnešním stavu jejich kutišt' Ryš stručně popisuje místa těžby manganové rudy, grafitu, magnetitu, uhlí, barytu, ohnivzdorných jílů a výrobu kamence z pyritu (Ryš 1931b). Ryšovy mineralogické výzkumy v okolí Jevíčka se odrazily v obsáhlém díle mineraloga Eduarda Burkarta (*1865, †1941) Mährens Minerale und ihre Literatur, v němž je Ryš často citován.

Josef Ryš se věnoval také paleontologickým sběrům, zejména miocenních zkamenělin u obce Borotín, jjz. od Jevíčka. Při sběru zkamenělin na tomto nalezišti spolupracoval s místními obyvateli; několik jich dokonce do sbírání zasvětil a oni mu se sběry pomáhali. V oblasti paleontologie spolupracoval s odborníky Moravského zemského muzea v Brně, konkrétně s kustodem geologicko-paleontologického oddělení Vladimírem Josefem Procházkou (*1862, †1913), který v letech 1893-1894 působil též v Národním muzeu v Praze. Do sbírek Moravského zemského muzea Ryš své paleontologické sběry z lokality Borotín v roce 1911 daroval (SOA Svitavy, fond č. 1246 Ryš Josef - dopis J. V. Procházky a poděkování Moravské musejní společnosti).

Ryš postupně shromáždil pestrou sbírku našich i zahraničních minerálů, čítající údajně 15 tisíc kusů (Továrek 1958). Ve sbírce byla i řada pro okolí Jevíčka jím nově objevených druhů. Sbírka zahrnovala nemálo výrazných hodnotných ukázek. Minerály si opatřoval z různých zdrojů. Kromě osobních sběrů také koupěmi od obchodníků, ale i výměnami se sběrateli a mineralogy. Ve státním okresním archivu Svitavy (se sídlem v Litomyšli) je dochována Ryšova korespondence, týkající se z velké části právě akvizic pro jeho sbírku. Jsou zde i dopisy od významných osobností jakými byli karsolog a archeolog Karel Absolon (*1877, †1960), geologové Radim Kettner (*1891, †1967), František Zvejška (*1901, †1954) a Břetislav Zahálka (*1883, †1958), mineralogové Tomáš Krut’a (*1906, †1998) a Josef Sekanina (*1901, †1986), pedolog Josef Pelíšek (*1901, †1993) či paleontolog Mauric Remeš $(* 1867, \dagger 1959)$ 
(Skořepa 2011). V častém kontaktu byl s mineralogem Masarykovy univerzity profesorem Josefem Sekaninou $(* 1901, \dagger 1986)$. S brněnským chemikem L. Prokešem plánoval prozkoumat „bauxity“ od Jevíčka. V korespondenci lze mezi jeho kontakty najít majitele dolů, lomů či firem zpracovávajících drahé a ozdobné kameny, psal si i se sběrateli a vědci z dalekých končin - z Kanady, Austrálie či Ruska; v kontaktu byl s Britským muzeem v Londýně (Továrek 1958). V pozůstalosti se také dochovaly sešity s Ryšovými záznamy o nově získaných ukázkách minerálů, o koupích, prodejích, výměnách, osobních sběrech; sešity obsahují i výpisky z odborné literatury, záznamy o vedené korespondenci a nákresy nalezišt'.

K dispozici jsou dva korespondenční lístky, které Josef Ryš zaslal mineralogovi Masarykovi univerzity v Brně Josefu Sekaninovi. V prvním z nich, z 5. 10. 1933 Ryš píše: „Vážený pane doktore, dovoluji si Vás uctivě poprositi o Váš nový separát o Dlouhé stěně u Jihlavy. Budu Vám velmi zavázán za laskavé zaslání. Posílám Vám současně své poslední separáty, ač nemají pro Vás významu, bylyt' určeny pro moje studenty a okolní učitelstvo ( $k$ výkladům vlastivědným). Předem srdečně děkuji, Váš v dokonalé úctě Josef Ryš, profesor státní reálky v Jevíčku."Ve druhém z 12. 10. 1933 pak píše: „Vážený pane doktore, príiměte srdečné díky za laskavě věnované separáty. Posílám Vám ty staré svoje, nehněvejte se, že jsou tak nevzhledné, nemám jich už, a tak jsem jen stěží je sehnal dohromady. Vyšlo to už asi před 25 léty, v programech státní reálky $v$ Jevíčku - a psáno je to ovšem hlavně pro studující reálky. o Vašem zpracování Dlouhé

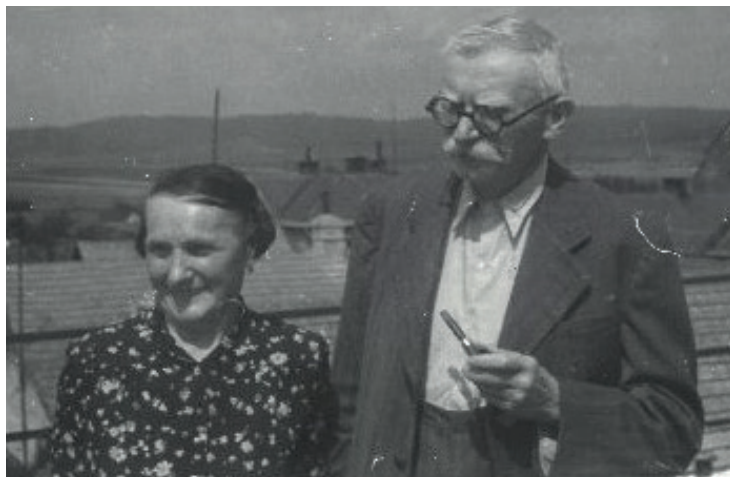

Obr. 13. Josef Ryš s manželkou Aloisií na fotografii z roku 1952 (SOA Svitavy, fond č. 1246 Ryš Josef). stěny mi psal kolega Dr. Ambrož

z Jihlavy, ale to se ale spletl s Jeclovem. Jsem Vám i za Jeclovskou monografii velmi povděčen, znal jsem to pouze z Vašeho stručného popisu v „Přírodě“. S přátelským pozdravem Váš dokonale oddaný Josef Ryš" (L. Kráčmar, soukromý archiv).

Za zmínku stojí také dopis, který 27. 2. 1946 zaslal Ryšovi Ing. Bohumil Iran, vedoucí provozu rafinace drahých kovi̊ mincovny v Kremnici, pravděpodobně absolvent reálky v Jevíčku a Ryšův žák. V dopise popisuje, jakým způsobem prožil válečná léta na Slovensku (v Kremnici a skrýváním v lesích). Ryšovi patrně zaopatřoval kremnické minerály do sbírky a sám byl sběratelem minerálů. $V$ dopise je také zmínka, z níž vyplývá, že jevíčské gymnaziální sbírky vzaly v době války zasvé (dopis je napsán krátce poté, co se Ryš vzdal vedení gymnázia; pisatelem je jednou osloven „pane řediteli“): „Nevím sice zcela přesně bylo-li i město Jevíćko zabráno, ale i když tomu tak nebylo, vládla tam ta vandalská sebranka nadlidí jistě stejně tak surově a vykrádala všecko jako všude jinde. Škoda těch krásných Vašich sbírek! (...) Zdejší doly na zlato byly také těžce poškozeny. Těžní zařízení a stroje němečtí vojáci zničili. Provádějí se tam nyní jen samé obnovovací, rekonstrukční práce, které budou trvat nejméně rok za předpokladu ovšem, že továrny dodají do té doby náhradní stroje atd. V dolech se nyní nepracuje, takže nyní byste, $p$. profesore, sotva odtud nějaké nerosty dostal. Až zase začnou fárat a něco bude, nezapomenu na Vás. Pátral jsem po svých věcech, které mi Němci ukradli, zde i v okolí, ale kromě několika knih - pošpiněných a potrhaných - které jsem našel pohozené na smetišti - neshledal jsem se s ničím. I moji sbírku minerálů prý odnesli a vysypali někam do potoka." (SOA Svitavy, fond č. 1246 Ryš Josef). K tomu jen dovětek, že v Ryšově sbírce se nacházelo pět ukázek zlata a tři ukázky antimonitu z Kremnice, které jsou dnes součástí sbírky Národního muzea. Jedna bohatá ukázka zlata z Kremnice (inv. č. P1N 47051) byla vybrána do nové mineralogické expozice Národního 


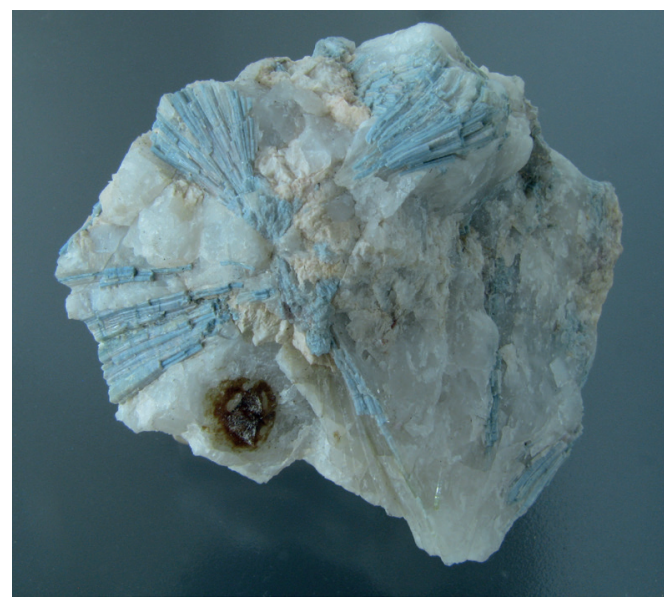

Obr. 14. Elbait - indigolit, Rožná, Morava, velikost vzorku $6 \times 5 \mathrm{~cm}$ (Národní muzeum P1N 47581, ex coll. J. Ryš). Foto: D. Velebil.

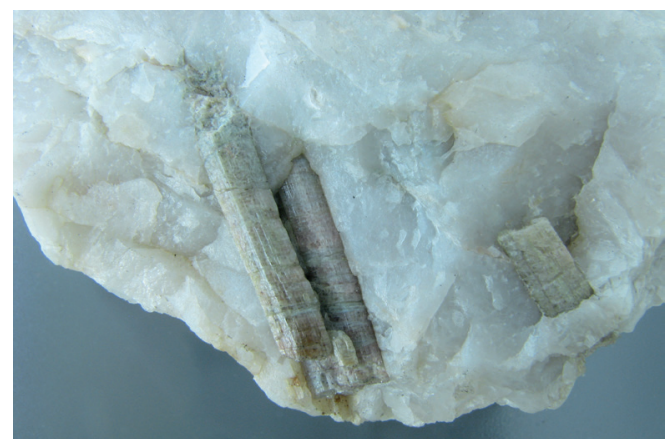

Obr. 15. Elbait - verdelit, Rožná, Morava, sloupcovité krystaly do 2 cm délky (Národní muzeum P1N 47579, ex coll. J. Ryš). Foto: D. Velebil.

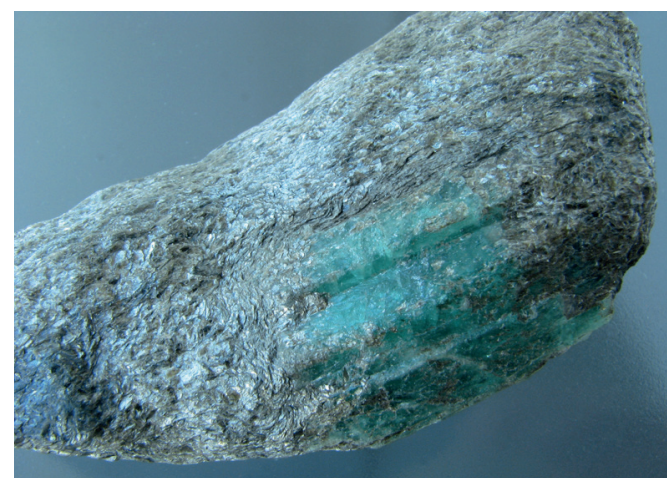

Obr. 16. Beryl - smaragd, Habachtal, Rakousko (nebo Ural, Rusko?), krystal velikosti 2,5 × $2 \mathrm{~cm}$ zarostlý v biotitickém svoru (Národní muzeum P1N 47543, ex coll. J. Ryš). Foto: D. Velebil. muzea. Z jiné zmínky se dozvídáme, že „Ryš uspořádal pro jevíčskou reálku bohaté sbírky minerálů a znovu je upravil po druhé světové válce, když při dočasném zrušení ústavu okupanty byly značně ztenčeny." (Továrek 1958), takže sbírky vzaly za války za své asi jen zčásti. Za německé okupace byly převezeny do reálného gymnázia $\mathrm{v}$ Boskovicích (Bubeník 1967) a mohly se po válce, přinejmenším z části, vrátit do Jevíčka.

V roce 1955 byl Josef Ryš pozván děkanem geologicko-geografické fakulty University Karlovy mineralogem prof. Rudolfem Rostem (*1912, †1999; v letech 1939-1946 pracoval v NM) na dvoudenní vědeckou konferenci pořádanou tímto ústavem (SOA Svitavy, fond č. 1246 Ryš Josef). S Rudolfem Rostem byl Ryš $\mathrm{v}$ kontaktu již dříve, v jeho písemné pozůstalosti se dochovaly také dva korespondenční lístky od Rudolfa Rosta z roku 1943, tedy z doby Rostova působení v Národním muzeu; v jednom z nich je Ryš pozdravován i od Karla Tučka (*1906, †1990), v letech 1939-1976 vedoucího mineralogicko-petrologického oddělení Národního muzea.

Národnímu muzeu daroval Josef Ryš v roce 1943 celkem 13 ukázek minerálů (Tuček 1978), zapsaných v tomto roce do inventáře pod čísly P1N 34412-34418 a P1N 34431-34436. Jsou to vzorky antigoritu, antofylitu, chromitu, kyanitu, fosilní pryskyřice - neudorfitu, opálu, palygorskitu a sepiolitu z různých moravských nalezišt' a jedna $50 \times 30 \mathrm{~cm}$ velká ukázka molybdenitu z Vidnavy u Žulové ve Slezsku (P1N 34431). V roce 1944 byla pod číslem P1N 34748 zapsána do inventáře mineralogické sbírky ukázka fosilní pryskyřice z Bělé u Jevíčka, získaná, stejně jako předchozí vzorky, od Josefa Ryše darem.

V roce 1941 věnoval Josef Ryš soubor lokálních minerálů muzeu v Jevíčku, kde se ovšem dochovalo jenom torzo tohoto souboru; většina kamenů byla patrně vyhozena $\mathrm{v}$ době dočasného zrušení muzea v 80. letech. 
Po válce přešla část Ryšovy mineralogické sbírky do sbírek Vysoké školy chemicko-technologické v Praze a další část do sbírek Palackého univerzity v Olomouci (viz níže). Další část sbírky, patrně nejkvalitnější kusy (tedy snad jakési jádro sbírky), si ovšem Josef Ryš ponechal.

Koupi části Ryšovy sbírky minerálů pro sbírku tehdejší Chemicko-technologické fakulty ČVUT (teprve od roku 1953 VŠCHT) vyjednal s Ryšem v roce 1947 vedoucí katedry mineralogie profesor Augustin Ondřej $(* 1887, \dagger 1956)$ (Bauer 1988). Od Jaroslava Bauera $(* 1920$, †1995), profesora mineralogie na VŠCHT, se o této akvizici dozvídáme, že Ryšova sbírka „... patřila totiž mezi jedny z nejlepších soukromých sbírek a obsahovala bohaté kolekce hlavně moravských, ale i českých a slovenských nerostů."Se souhlasem ministerstva školství byla sbírka pro VŠCHT v Praze zakoupena za 150000 Kčs. Sbírka, uložená v 80 bednách, prý obsahovala 5480 kusů minerálů a byly zde např́íklad krásné ukázky japonských antimonitů a mědi z Nandraže (Bauer 1988). V souboru minerálů, které si Ryš ponechal až do své smrti a které později přešly do Národního muzea (viz dále v tomto textu), se přitom nacházelo 17 dalších vzorků nandražské mědi, dnes ceněných a špatně dostupných, a další japonský antimonit.

Ve sbírce Vysoké školy chemicko-technologické jsou Ryšovy minerály evidovány pod inventárními čísly 21281-22633, což představuje 1353 položek. Augustin Ondřej uvedl u každého kusu cenu, přičemž součet jednotlivých cen činí 162990 Kčs. Rozpor mezi údajem o počtu kusů

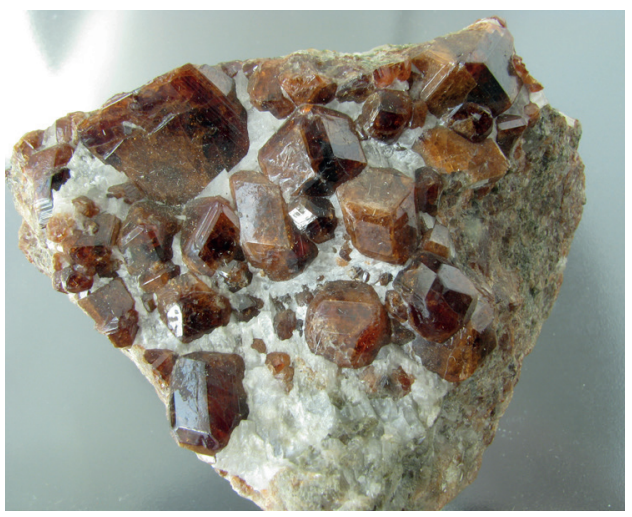

Obr. 17. Grosulár - hesonit, Žulová, Slezsko, velikost vzorku $9 \times 6 \mathrm{~cm}$ (Národní muzeum P1N 47638, ex coll. J. Ryš). Foto: D. Velebil. uvedeným Bauerem (1988) a stavem skutečným je vysvětlován chybou v Bauerově publikaci (D. Koloušek, správce mineralogické sbírky VŠCHT, osobní sdělení 2020). V sbírkovém sále, v němž je mineralogická sbírka VŠCHT uložena a vystavena, dodnes visí mezi dalšími portréty mineralogů i Ryšův fotografický portrét z roku 1950 (Koloušek 2020, osobní sdělení).

V roce 1948 nebo 1949 získalo od Ryše ukázky minerálů také Moravské zemské muzeum v Brně (Krut’a 1949). Z Ryšových poznámek (SOA Svitavy, fond č. 1246 Ryš Josef) vyplývá, že v roce 1952 čítala jeho sbírka minerálů 3943 kusů, ale již o rok později, v roce 1953 pouze 1944 kusů. Tento pohyb ve sbírce (2000 kusů) by mohl odpovídat přesunu minerálů na Palackého univerzitu v Olomouci. Zbylý počet 1944 kusů zhruba odpovídá počtu zapsanému do př́růstkové knihy mineralogicko-petrologického oddělení Národního muzea v roce 1961, tedy po Ryšově smrti.

O minerálech z části Ryšovy sbírky na Palackého univerzitě se zmiňují Kruta (1994, 1997), Staněk (2002) a Rejl (Rejl, nedatováno, MS In: archiv osobností-sběratelů, mineralogicko-petrologické oddělení Národní muzea, složka Ryš Josef). Krut’a (1997) ovšem zároveň uvádí, že k roku 1997 Ryšova sbírka na Palackého univerzitě nebyla. Mineralog Jiří Zimola z Katedry geologie Př́rodovědecké fakulty Univerzity Palackého v Olomouci se vyjádřil v tom smyslu, že asi rok nebo dva po svém nástupu na fakultu v roce 1983 viděl „tu Ryšovu sbírku miniatur zabalenou v novinách", soubor prý neobsahoval nic cenného či zajímavého (Zimola in Skořepa 2011). Zdá se, že Ryšovy minerály na Palackého univerzitě vzaly za své během povodní v červenci 1997, kdy byly zaplaveny i sklepní prostory Přírodovědecké fakulty Univerzity Palackého (Skořepa 2011).

Ještě v 50. letech se Ryš snažil vytvářet učební soubory minerálů a hornin pro školy, s tímto projektem se ovšem, jak se zdá, př́liš neprosadil. Zájem o př́rodní vědy si Josef Ryš udržel až do konce svého života, zemřel 21. května 1960 v Jevíčku. Pohřben byl na místním hřbitově 
(Krut'a 1960, 1997). Dnes je jeho jméno uvedeno na náhrobku společně s dalšími jedenácti členy rodiny Vrbkových, Ryšových a Effenbergových.

\section{Ryšovy minerály v Národním muzeu}

Po Ryšově smrti požádal jeho syn akademik Přemysl Ryš (*1919, †2005), ředitel Ústavu fyzikální metalurgie ČSAV v Brně, mineraloga Moravského muzea v Brně Tomáše Krut'u (*1906, †1998), aby ocenil zbylou část sbírky minerálů, která zůstala v rodině. Minerály byly uloženy v objektu bývalé Janouškovy pekárny v zadním traktu domu na Palackého náměstí 2 , kde Ryš se svou rodinou bydlel. Tomáš Krut’a se s Josefem Ryšem seznámil již někdy okolo roku 1925 při svých terénních exkurzích do okolí obce Hřebeč, sz. od Jevíčka, kde sbíral fosilní pryskyřici, markazit a sádrovec (Krut’a 1997). Podle Krutových vzpomínek byla Ryšova mineralogická sbírka pěkně vedená, vzorky byly opatřeny etiketami a celá sbírka byla vybavena katalogem. Odměnou za ocenění sbírky získal Tomáš Krutáa výrazný vzorek krystalu berylu v pegmatitu z Maršíkova u Šumperka. Ve sbírce se prý nacházela další pěkná ukázka berylu, a to větší krystal smaragdu zarostlý ve svoru, ze slavného rakouského naleziště Habachtal; Kruta později litoval, že jej nezískal také (Krut’a 1997). „Unikátní exemplář smaragdu z Habachtalu“ v Ryšově sbírce zmínil Kruta i ve svých vzpomínkách z roku 1994 (Krut’a 1994).

Poslední část Ryšovy mineralogické sbírky zakoupilo v roce 1961 Národní muzeum v Praze (Tuček 1978). Do př́růstkové knihy mineralogicko-petrologického oddělení Národního muzea byla tato akvizice zapsána 21. 6. 1961 pod přírůstkovým číslem P1P 43/61 s popisem „1900 kusů nerostů moravských i zahraničních, ČSR i cizina, koupí za 13 000,- od J. Vrbkové, Jevíčko, Palackého n. 29“ (Jaroslava Vrbková - dcera J. Ryše). Kouřimský (1962) vyzdvihl z této akvizice především minerály z moravských nalezišt'. Podle následných zápisů $\mathrm{v}$ př́růstkové knize byl soubor posléze zaevidován do systematické evidence pod inventárními čísly P1N 47047-47959 (minerály), P1M 392-393 (meteority), P1H 11788 (horniny).

Minerály byly do systematické evidence mineralogické sbírky zaevidovány ještě během roku 1961, a to celkem 913 položek př́růstku P1P 43/61 (výše uvedená inventární

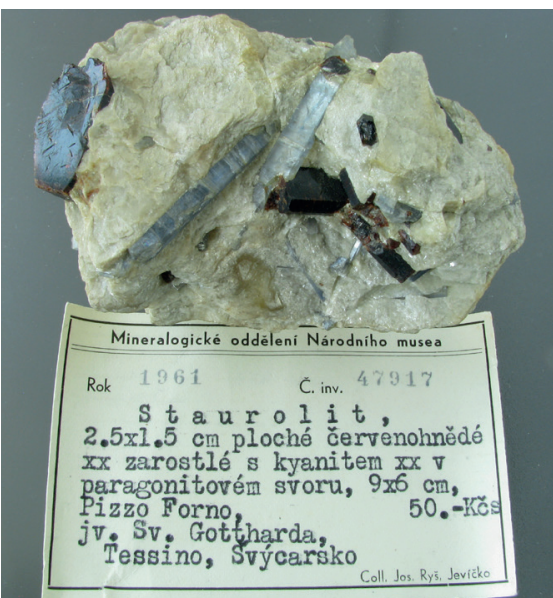

Obr. 18. Staurolit s kyanitem, Pizzo Forno, Švýcarsko, velikost vzorku $9 \times 6 \mathrm{~cm}$ (Národní muzeum P1N 47917, ex coll. J. Ryš). Foto: D. Velebil.

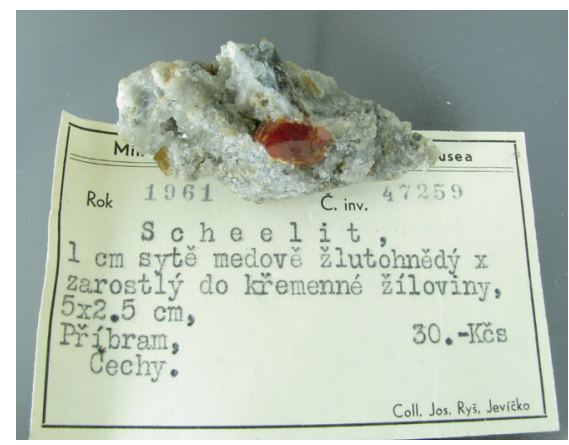

Obr. 19. Scheelit, Příbram, Čechy, $12 \mathrm{~mm}$ velký krystal, velikost vzorku 5,5 × 2,5 cm (Národní muzeum P1N 47259, ex coll. J. Ryš). Foto: D. Velebil. čísla P1N 47047-47959). U každého minerálu je uveden původce sbírky („coll. J. Ryš, Jevíčko“) a cena. Není zřejmé, jestli jsou uvedené ceny kupní, stanovené pro jednotlivé kameny Krutou, anebo byly pořízené až při zapisování minerálů do systematické evidence, nicméně jejich součet činí 13 612,- Kčs (průměrně 15 
Kčs za položku), což dobře koresponduje s kupní cenou celého souboru (13 $000 \mathrm{Kčs}$ ). Do systematické evidence sbírky hornin Národního muzea byl pod číslem P1H 11788 zaevidován pouze jediný vzorek, a to bílá leštěná deska průsvitného mramoru $\mathrm{z}$ italské Carrary o velikosti $12 \times 8 \mathrm{~cm}$. Kromě minerálů a jedné horniny byly z části Ryšovy sbírky, zakoupené Národním muzeem, zaevidovány i dva meteority, a to plochý celotvar polského meteoritu Pultusk o hmotnosti $23 \mathrm{~g}$ a rozměrech $4,5 \times 3 \times 0,5 \mathrm{~cm}(\mathrm{P} 1 \mathrm{M} 392)$ a $2 \mathrm{~kg}$ odřez meteorického železa Blackall (Austrálie) o rozměrech $12 \times 8 \times 7 \mathrm{~cm}$ (P1M 393).

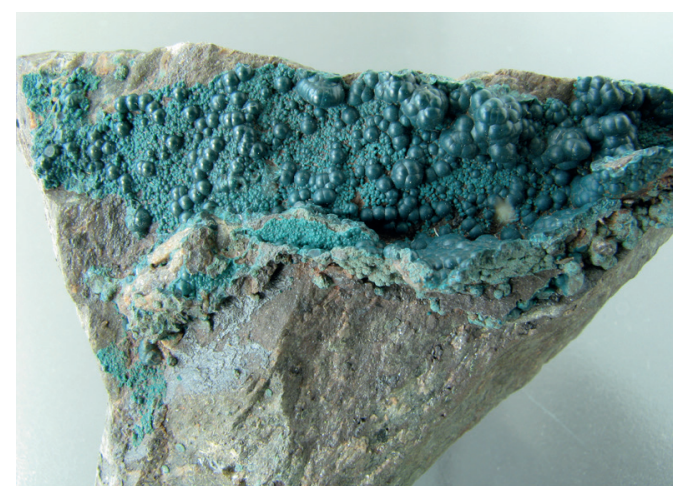

Obr. 20. Pseudomalachit, Krucemburk, Čechy, velikost vzorků $7 \times 4 \mathrm{~cm}$ (Národní muzeum P1N 47213, ex coll. J. Ryš). Foto: D. Velebil.

Počet zaevidovaných kusů minerálů neodpovídá číselnému údaji uvedenému v přírůstkové knize. Rozdíl lze vysvětlit chybným odhadem počtu před zápisem do př́růstkové knihy anebo tím, že byla záměrně zaevidována jenom část celého souboru a nepotřebné minerály byly posléze použity na výměnu či prodej. $V$ doprovodné dokumentaci sbírek mineralogické a petrologické se dnes nenachází žádný soubor minerálů či hornin označených původem jako od Ryše.

V souboru 913 minerálů uložených v mineralogické sbírce Národního muzea je zastoupeno celkem 165 druhů. Převládají ukázky z nalezišt' moravských (celkem 270 položek), dále z lokalit v Čechách (celkem 243 položek), mezi nimi např́klad $2 \times 0,5 \mathrm{~cm}$ velký plech zlata z Křepic (P1N 47047) či 2,5 × 1,5 cm velká skupina až $1 \mathrm{~cm}$ krystalů proustitu z Jáchymova (P1N 47146), cenné jsou také například dva výrazné vzorky pseudomalachitu z Krucemburku vsv. od Havlíčkova Brodu (P1N 47213 a 47214). Ze slezských nalezišt' pochází 15 ukázek, z toho je devět grosulárů - hesonitů ze Žulové (P1N 47636-47644), mezi nimi i velmi estetické ukázky; ze Slovenska je 192 položek minerálů. Ze studia Ryšových životopisných dat lze nabýt dojmu, že těžištěm jeho sběratelství byly lokální osobní sběry z nalezišt' severomoravských a východočeských. Skutečnost je ovšem taková, že Ryš měl ve své sbírce i velmi pěkné minerály zahraniční, např́iklad ze Spišsko-Gemerské oblasti na Slovensku (pěkné albity z Rožňavy, siderity z Rožňavy, Mlynek, Nižné Slané aj.), pět bohatých ukázek zlata z Kremnice (P1N 47048-47052) a tři z rumunské Rosia Montany (P1N 47054-47056), jedinečný je soubor 17 vzorků mědi ze slovenské Nandraže (P1N 47057-47073) atd. Dalšími zeměmi, zastoupenými v Ryšově kolekci ukázkami minerálů, jsou: Rumunsko (38) - včetně velmi pěkného tetraedritu z lokality Botes (P1N 47125), Německo (32), Itálie (20) - včetně esteticky výrazného hematitu z Rio Marina na Elbě (P1N47355) a Rakousko (17) - mezi rakouskými minerály i smaragd z Habachtalu (P1N 47543) ${ }^{1}$ zmiňovaný Krutou (1994, 1997), dále Kosovo (13), Rusko (13), USA (10), Anglie (9), Švýcarsko (8), Polsko (5), Island (3), Namibie (3), Bosna a Hercegovina (2), Finsko (2), Kanada (2), Madagaskar (2), Slovinsko (2), Španělsko (2), Ukrajina (2); po jednom minerálu je z Austrálie, Brazílie, Francie, Grónska, Indie, Japonska, Norska a Srí Lanky.

Z neznámého důvodu se, bohužel, nedochovaly Ryšovy původní etikety; vzorky v Národním muzeu jsou vybaveny pouze nově vytvořenými etiketami muzejními s uvedením původce „Coll. Jos. Ryš, Jevíčko“. O kvalitě sbírky minerálů Josefa Ryše jasně vypovídá

1 Zdá se, že smaragd s deklarovanou lokalitou Habachtal, Rakousko je podle vnějšího charakteru spíše z Uralu v Rusku a pro tuto lokalitu je to vzorek spíše podprůměrný. Velikost krystalů smaragdu z Uralu je řádově větší než z klasické rakouské lokality Habachtal. Pro uralský původ svědčí světlá barva krystalu, zaoblení hran mezi plochami hexagonálního prismatu a hrubě šupinatý charakter biototického svoru, v němž je krystal zarostlý. 
fakt, že v roce 2018 bylo z Ryšova souboru vybráno do připravované nové expozice minerálů Národního muzea celkem 65 ukázek minerálů, nejvíce českých a slovenských, ale i nemálo zahraničních.

\section{Závěr}

Středoškolský profesor Josef Ryš byl člověk vzdělaný, činorodý, skromný a pracovitý, svými zájmy mnohostranně zaměřený. Byl to přesvědčený český vlastenec a sokol. Kromě dětských a studentských let prožil celý svůj život v Jevíčku, které si zamiloval a stal se lokálním patriotem. Zdejší krajinu poznával a k jejímu poznání vedl i své studenty. Z tohoto poznávání pak čerpal pro své odborné vlastivědné a geologické práce, týkající se v první řadě nerostného bohatství a výskytu minerálů $\mathrm{v}$ regionu mezi Boskovicemi a Moravskou Třebovou.

Josef Ryš vybudoval dokumentačně velmi cennou sbírku českých i světových minerálů. Jádro jeho mineralogické sbírky odkoupilo $\mathrm{v}$ roce 1961, tedy krátce po Ryšově smrti, Národní muzeum v Praze, kde je dodnes uchováno celkem 913 minerálů z jeho sbírky a dva meteority. Celkem 65 ukázek minerálů z Ryšovy sbírky bylo vybráno do stálé mineralogické expozice Národního muzea v Praze.

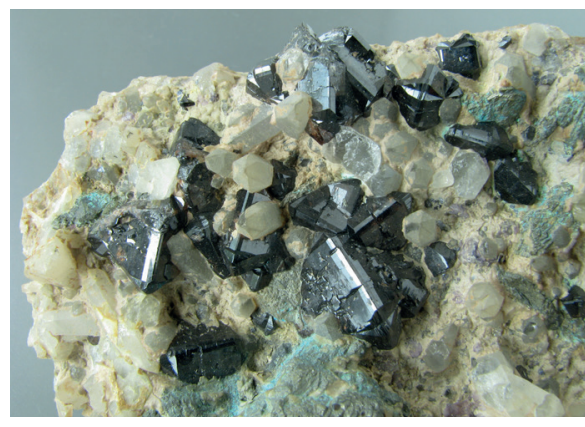

Obr. 21. Kasiterit, Horní Slavkov, Čechy, skupina až 15mm krystalů (Národní muzeum P1N 47367, ex coll. J. Ryš). Foto: D. Velebil.

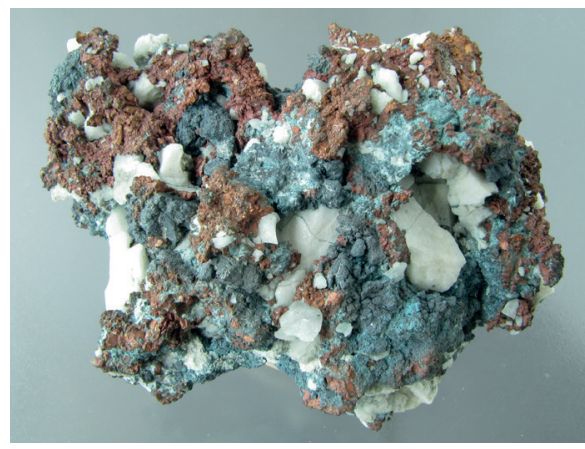

Obr. 22. Měd', Nandraž, Slovensko, velikost vzorku 7 × 5 cm (Národní muzeum P1N 47068, ex coll. J. Ryš). Foto: D. Velebil.

\begin{tabular}{|c|c|c|c|c|c|}
\hline invent. číslo & minerál (název) & varieta & lokalita & stát & velikost \\
\hline 47780 & aktinolit & & Sobotín & Morava & $11 \times 8 \mathrm{~cm}$ \\
\hline 47676 & albit & & Rožňava & Slovensko & $6 \times 5 \mathrm{~cm}$ \\
\hline 47677 & albit & & Rožňava & Slovensko & $9 \times 6 \mathrm{~cm}$ \\
\hline 47866 & ankerit & & Mlynky & Slovensko & $12 \times 9 \mathrm{~cm}$ \\
\hline 47867 & ankerit & & Mlynky & Slovensko & $13 \times 8 \mathrm{~cm}$ \\
\hline 47174 & antimonit & & Baia Sprie & Rumunsko & $8 \times 6 \mathrm{~cm}$ \\
\hline 47884 & aragonit & & Hřídelec - Horka & Čechy & $10 \times 8 \mathrm{~cm}$ \\
\hline 47151 & argentit & & Schneeberg & Německo & $4 \times 3 \mathrm{~cm}$ \\
\hline 47114 & arsenopyrit & & Freiberg & Německo & $11 \times 8 \mathrm{~cm}$ \\
\hline 47113 & arsenopyrit & & Příbram & Čechy & $8 \times 6 \mathrm{~cm}$ \\
\hline 47235 & baryt & & Příbram & Čechy & $6 \times 5 \mathrm{~cm}$ \\
\hline 47540 & beryl & & Meclov & Čechy & $9 \times 4 \mathrm{~cm}$ \\
\hline 47542 & beryl & smaragd & Tokovaja & Rusko & $11 \times 7 \mathrm{~cm}$ \\
\hline 47187 & bournonit & & Př́íbram & Čechy & $8 \times 6 \mathrm{~cm}$ \\
\hline 47502 & bournonit & & Příbram & Čechy & $12 \times 8 \mathrm{~cm}$ \\
\hline 47616 & epidot & & Petrov nad Desnou & Morava & $6 \times 5 \mathrm{~cm}$ \\
\hline 47225 & evansit & & Nižná Slaná & Slovensko & $9 \times 7 \mathrm{~cm}$ \\
\hline 47271 & farmakosiderit & & Nová Baňa & Slovensko & $7 \times 3 \mathrm{~cm}$ \\
\hline 47715 & fluorit & & Litice nad Orlicí & Čechy & $7 \times 5 \mathrm{~cm}$ \\
\hline
\end{tabular}




\begin{tabular}{|c|c|c|c|c|c|}
\hline 47194 & galenit & & Stříbro & Čechy & $9 \times 7 \mathrm{~cm}$ \\
\hline 47633 & granát & & Petrov nad Desnou & Morava & $9 \times 5 \mathrm{~cm}$ \\
\hline 47639 & grosulár & hesonit & Žulová & Slezsko & $10 \times 6 \mathrm{~cm}$ \\
\hline 47644 & grosulár & hesonit & Žulová & Slezsko & $9 \times 6 \mathrm{~cm}$ \\
\hline 47355 & hematit & & Rio Marina & Itálie & $13 \times 8 \mathrm{~cm}$ \\
\hline 47182 & heteromorfit & & Příbram & Čechy & $11 \times 9 \mathrm{~cm}$ \\
\hline 47330 & kalcit & & Brad & Rumunsko & $10 \times 6 \mathrm{~cm}$ \\
\hline 47404 & křemen & & Stříbro & Čechy & $9 \times 7 \mathrm{~cm}$ \\
\hline 47420 & křemen & záhněda & Etzlithal & Švýcarsko & $9 \times 7 \mathrm{~cm}$ \\
\hline 47414 & křemen & křištál & Sankt Gotthard & Švýcarsko & $12 \times 8 \mathrm{~cm}$ \\
\hline 47949 & labradorit & & St. Paul Island & Kanada & $10 \times 6 \mathrm{~cm}$ \\
\hline 47927 & magnesit & & Jelšava & Slovensko & $13 \times 9 \mathrm{~cm}$ \\
\hline 47296 & magnetit & & Cavo - důl Rio Albano & Itálie & $8 \times 6 \mathrm{~cm}$ \\
\hline 47729 & malachit & & Nižní Tagilsk & Rusko & $11 \times 7 \mathrm{~cm}$ \\
\hline 47939 & malachit & & Rožňava & Slovensko & $8 \times 7 \mathrm{~cm}$ \\
\hline 47382 & manganit & & Železník & Slovensko & $7 \times 5 \mathrm{~cm}$ \\
\hline 47180 & millerit & & Pchery & Čechy & $10 \times 6 \mathrm{~cm}$ \\
\hline 47690 & natrolit & & Markovice & Čechy & $10 \times 6 \mathrm{~cm}$ \\
\hline 47442 & opál & & Nová Ves & Morava & $7 \times 6 \times 3 \mathrm{~cm}$ \\
\hline 47451 & opál & & Nová Ves & Morava & $10 \times 8 \times 4 \mathrm{~cm}$ \\
\hline 47481 & opál & dřevitý & Šajba & Slovensko & $8 \times 7 \mathrm{~cm}$ \\
\hline 47610 & opál & drahý & Queensland & Austrálie & $9 \times 7 \mathrm{~cm}$ \\
\hline 47666 & ortoklas & & Chodov & Čechy & $12 \times 9 \mathrm{~cm}$ \\
\hline 47681 & ortoklas & & San Piero in Campo & Itálie & $11 \times 7 \mathrm{~cm}$ \\
\hline 47145 & polybasit & & Hodruša & Slovensko & $3 \times 1,5 \mathrm{~cm}$ \\
\hline 47759 & prehnit & & Markovice & Čechy & $13 \times 9 \mathrm{~cm}$ \\
\hline 47112 & pyrhotin & & Chiuzbaia & Rumunsko & $8 \times 7 \mathrm{~cm}$ \\
\hline 47084 & pyrit & & Příbram & Čechy & $7 \times 5 \mathrm{~cm}$ \\
\hline 47378 & rutil & & Revúca & Slovensko & $6 \times 5 \mathrm{~cm}$ \\
\hline 47260 & scheelit & & Cínovec & Čechy & $8 \times 7 \mathrm{~cm}$ \\
\hline 47902 & siderit & & Př́bram & Čechy & $11 \times 6 \mathrm{~cm}$ \\
\hline 47901 & siderit & & Nižná Slaná & Slovensko & $11 \times 7 \mathrm{~cm}$ \\
\hline 47721 & siderit & & Betliar & Slovensko & $12 \times 5 \mathrm{~cm}$ \\
\hline 47874 & siderit & & Rožňava & Slovensko & $11 \times 9 \mathrm{~cm}$ \\
\hline 47718 & siderit & & Rožňava & Slovensko & $11 \times 9 \mathrm{~cm}$ \\
\hline 47900 & siderit & & Rožňava & Slovensko & $15 \times 13 \mathrm{~cm}$ \\
\hline 47955 & smithsonit & & Altenberg & Německo & $10 \times 7 \mathrm{~cm}$ \\
\hline 47624 & staurolit & & Sobotín - Trouznice & Morava & $8 \times 5 \mathrm{~cm}$ \\
\hline 47142 & stefanit & & Banská Štiavnica & Slovensko & $10 \times 7 \mathrm{~cm}$ \\
\hline 47125 & tetraedrit & & Botes & Rumunsko & $7 \times 6 \mathrm{~cm}$ \\
\hline 47764 & titanit & & St. Gotthard & Švýcarsko & $9 \times 6 \mathrm{~cm}$ \\
\hline 47844 & valchovit & & Janůvky & Morava & $13 \times 7 \mathrm{~cm}$ \\
\hline 47257 & wulfenit & & Mežica & Slovinsko & $11 \times 7 \mathrm{~cm}$ \\
\hline 47051 & zlato & & Kremnica & Slovensko & $10 \times 4 \mathrm{~cm}$ \\
\hline 47055 & zlato & & Rosia Montana & Rumunsko & $5 \times 3 \mathrm{~cm}$ \\
\hline 47056 & zlato & & Rosia Montana & Rumunsko & $6 \times 3 \mathrm{~cm}$ \\
\hline
\end{tabular}

Tab. 1. 65 minerálů vybraných do nové expozice Národního muzea představuje výčet nejlepších ukázek z Ryšovy sbírky. 


\section{Poděkování}

Tato práce vznikla za finanční podpory Ministerstva kultury ČR v rámci institucionálního financování dlouhodobého koncepčního rozvoje výzkumné organizace Národní muzeum DKRVO 2019-2023/15.I.b, 00023272).

Za poskytnutí některých pramenů a další cenné informace děkujeme badatelům Martinu Bohatému (Brno) a Lud'ku Kráčmarovi (Brno).

Děkujeme i oběma recenzentům, jednomu anonymnímu a F. Vackovi (Národní muzeum) za připomínky k rukopisu.

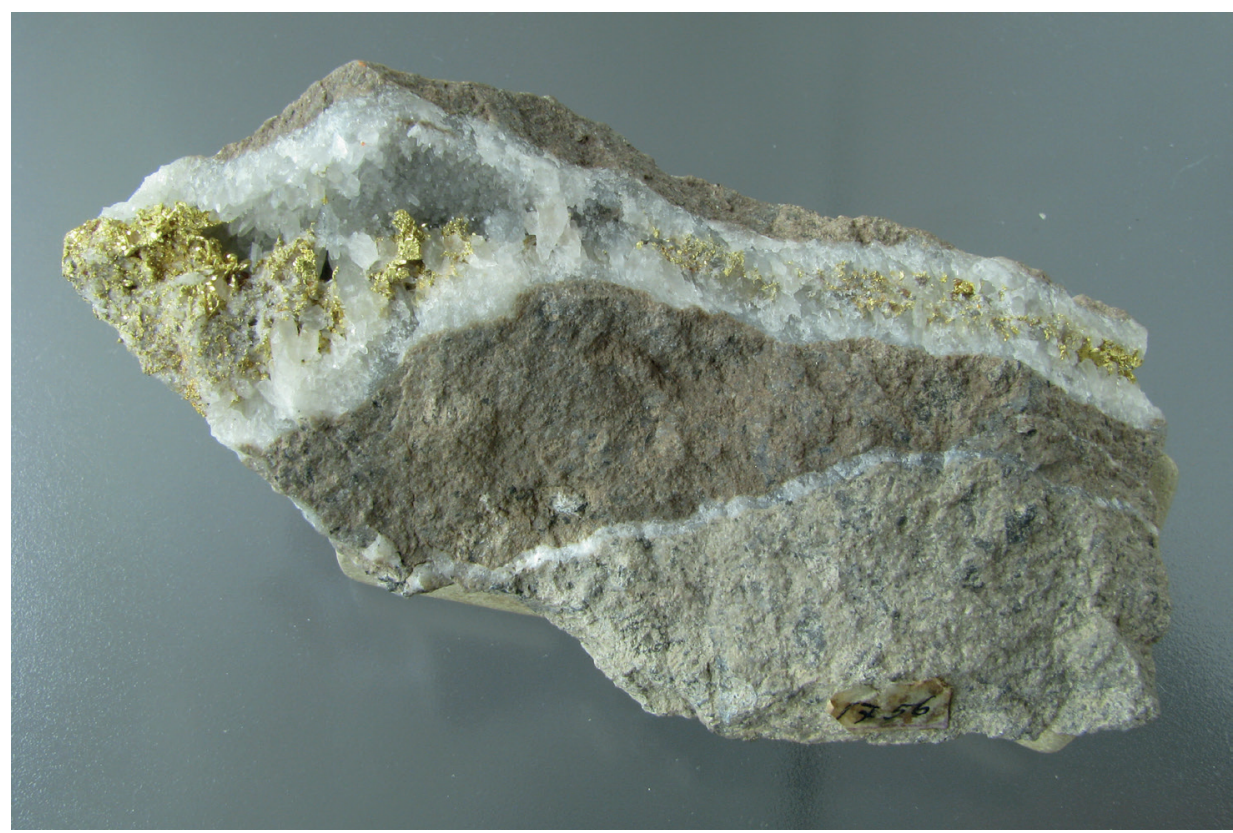

Obr. 22. Zlato, Kremnica, Slovensko, velikosti vzorku 8 × 4 cm (Národní muzeum P1N 47050, ex coll. J. Ryš). Foto: D. Velebil.

\section{Literatura}

Bauer J., 1988: Mineralogické sbírky Vysoké školy chemicko-technologické v Praze. - Sborník Vysoké školy chemicko-technologické v Praze, G 23 (1988). Mineralogie. 110 pp.

Bubeník O. (ed.), 1967: Sborník 70 let střední školy v Jevíčku 1897-1967. - Nákladem SRPŠ a ZV ROH při Stř̌ední všeobecně vzdělávací škole v Jevíčku (tištěno v Havlíčkově Brodě).

Kouřimský J., 1962: Zpráva o činnosti mineralogického oddělení Národního muzea v roce 1961. - Časopis Národního muzea, oddíl př́rodovědný 131, 3: 174-177.

Kruta T., 1949: Oddělení mineralogicko-petrografické. - Časopis Moravského musea v Brně 34, 1 - př́rodní vědy: 98-101.

Kruta T., 1960: Profesor Josef Ryš zemřel. - Časopis pro mineralogii a geologii 5, 4: 494-495. Krut’a T., 1994: Z mých vzpomínek. - Minerál 2, 3: 121-125.

Krut’a T., 1997: Z mých vzpomínek (20.) - Profesor Josef Ryš z Jevíčka (1879-1960). - Minerál 5, 3: 203.

Ryš J., 1909: Geologické poměry okolí Jevíčského. - Výroční zpráva státní reálky v Jevíčku I. 1908/1909. Pp. 1-14. 
Ryš J., 1910: Geologické poměry okolí Jevíčského. - Výroční zpráva státní reálky v Jevíčku II. $1909 / 1910$.

Ryš J., 1911: Geologické poměry okolí Jevíčského. - Výroční zpráva státní reálky v Jevíčku III. 1910/1911. Pp. 1-19.

Ryš J., 1912: Geologické poměry okolí Jevíčského. 3. Horstvo na východě Malé Hané. - Výroční zpráva státní reálky v Jevíčku IV. 1911/1912. Pp. 1-15.

Ryš J., 1912: Technicky důležité horniny jevíčského kraje. - Týdeník Nová Malá Haná. Jevíčko.

Ryš J., 1931: Drobné zprávy a referáty: Naleziště malachitu u Jevíčka - Časopis Vlastivědného spolku musejního, Olomouc 44, 3-4: $284 .^{2}$

Ryš J., 1931: O cenných nerostech v okolí Jevíčka a o dnešním stavu jejich kutišt' - Časopis Vlastivědného spolku musejního, Olomouc, 2. oddíl přírodovědný 44, 3-4: 238-239.

Ryš J., 1931: Obraz okolí města Jevíčka. - Vlastivědný sborník moravskoslezský, Brno.

Ryš J., 1931: Nerosty a horniny v okolí Jevíčka. - Výroční zpráva státní reálky v Jevíčku za rok 1930/1931. Pp. 1-11.

Ryš J., 1937: 40 let české reálky v Jevíčku. - Neidentifikovaná edice, volně vloženo v kronice Gymnázia v Jevíčku, 16 pp.

Ryš J., 1940: Těžba uhlí v Hor. Smržově. - Časopis vlastivědného spolku musejního, Olomouc 53, sv. II. oddíl př́rodovědný, (postupné číslo sešitu č. 199 a 200): 181.

Ryš J., 1958: Nerostné bohatství politického okresu moravsko-třebovského a jeho využití. - Vydal odbor pro školství a kulturu rady Okresního národního výboru v Moravské Třebové: 1-31.

Skořepa H., 2011: Josef Ryš - středoškolský profesor a geolog Malé Hané. - Moravskotřebovské vlastivědné listy, Městské muzeum Moravská Třebová 21: 62-66.

Skřivánek M., 1987: Osobní fond Josefa Ryše (1879-1960). - MS, inventář, SOA Litomyšl.

Staněk J., 2002: Mineralogie na Moravě a ve Slezsku v letech 1770-1970. - Folia Historica 71, Faculty of Science Masaryk University Brno, 1-65 (Ryš: p. 36).

Továrek F., 1958: Ve znamení pera, Jevíčko a Malá Haná v literatuře. - Jevíčko, 82 pp.

Tvrzník B., 1961: Ryš Josef. - In: Naučný geologický slovník, 2. díl N-Ž, Nakladatelství Československé akademie věd Praha, p. 770.

Tuček K., 1978: Kapitoly z dějin mineralogicko-petrografického oddělení Národního muzea v Praze. - Časopis Národního muzea, řada přírodovědná 147, 1-4: 1-142 (Ryš: pp. 96, 112).

\section{Archivní fondy}

Státní okresní archiv Svitavy se sídlem v Litomyšli, fond č. 1246 Ryš Josef, 1893-1959 (1961), personálie, korespondence, písemnosti týkající se geologické sbírky, obrazové dokumenty (u Jaroslavy Vrbkové, dcery J. Ryše, zajistil v roce 1960 Jaroslav Mackerle).

Archiv osobností-sběratelů, mineralogicko-petrologické oddělení Národní muzea, složka Ryš Josef.

\section{Kroniky}

Kronika Gymnázia v Jevíčku psaná od školního roku 1897/1898, Jevíčko.

\section{Internetové zdroje}

Šubr P. (nedatováno): Vítězslav Fr. Hlaváč a jeho muzeum. - http://www.lazne-belohrad.cz/ osobnosti-mesta/vitezslav-fr-hlavac/ [přístup 2. 5. 2020]

Muzeum východních Čech v Hradci Králové: Historie sbírky, zhodnocení stavu sbírky a její popis obecně. - https://www.muzeumhk.cz/muzeum/sbirky.html [př́stup 2. 5. 2020]

2 Díky redakční chybě Časopisu Vlastivědného spolku musejního Olomouc mohou být Josefu Ryšovi připisovány ještě další tři krátké př́ispěvky uveřejněné na stranách 283-384, čísla 3-4, ročníku 44 s názvy „Černotínské

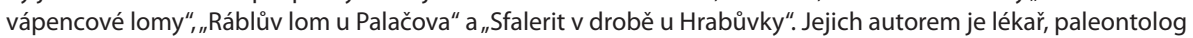
a prírodovědec v nejširším slova smyslu Mauric Remeš (*1867, †1959) - příjmení obou badatelů začínají a končí stejnými písmeny. 


\section{Summary}

Josef Ryš $(* 1879, \dagger 1960)$ was a high school professor in Jevíčko Town on NW Moravia, geologist and mineralogist. He has published 11 works on the geological and mineralogical conditions of the surroundings of Jevíčko. He was born in Prague, where he studied grammar school and also graduated from natural sciences at Charles University. From 1903, he lived and worked in Jevíčko, where he also married and had two children. In 1917 and 1918 he fought as a soldier in the Austrian army in the Balkans and Italy. He was the head of the physical education organization Sokol in Jevíčko. As a researcher, he was in contact with mineralogists and geologists of the Moravian Museum in Brno, Masaryk University in Brno, Charles University in Prague and the National Museum in Prague. He retired in 1939. Josef Ryš built a nice collection of Czech and world minerals, which he procured through personal collecting, exchanges and purchases. During his lifetime, he donated a number of personally collected minerals, rocks and fossils to the following institutions: the V. F. Hlaváč Museum of Natural History in Lázně Bělohrad, the Agricultural Institute in Hradec Králové, the Moravian Museum in Brno, the University of Chemical Technology in Prague, Palacký University in Olomouc, the Museum in Jevíčko and the National Museum in Prague. However, he kept the core of his mineralogical collection. The main work of Ryš's publishing activities is the thirty-page handbook Mineral Wealth and its Utilization of the Moravská Třebová Political District from 1958, in which the author notes not only the mineralogical conditions of the area, but also the mining and processing of minerals. Josef Ryš died in Jevíčko. After his death, his collection of minerals was bought in 1961 by the National Museum in Prague, where a total of 913 minerals from his collection and two meteorites are still preserved. A total of 65 samples of minerals from Ryš's collection were selected for the permanent mineralogical exhibition in the National Museum in Prague.

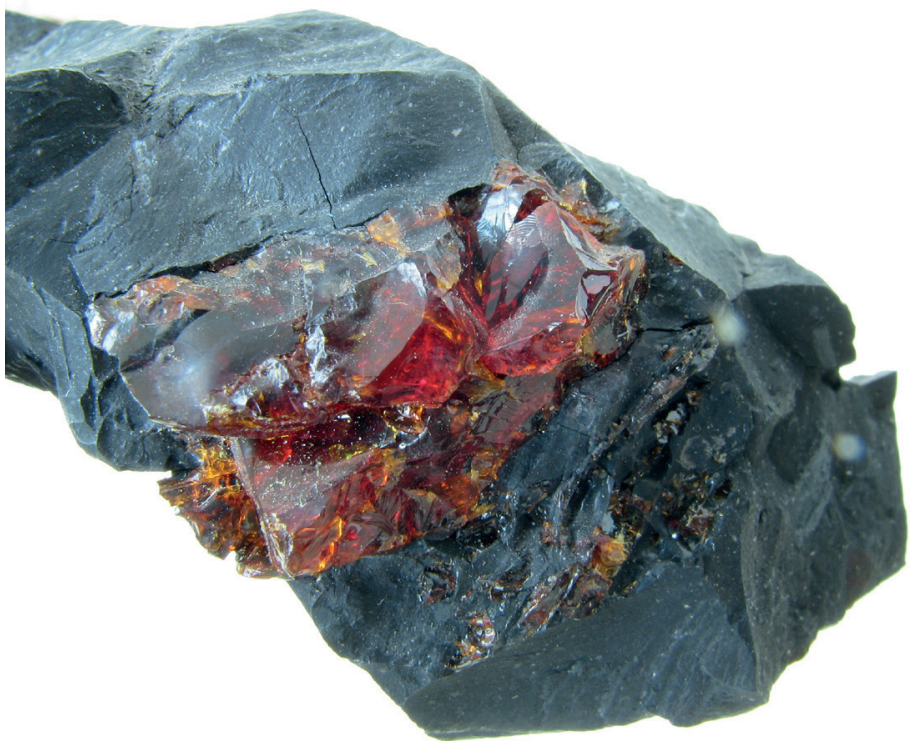

Obr. 23. Neudorfit, Janůvky, sz. od Jevíčka, hlíza velikosti $2,5 \times 1,5 \mathrm{~cm}$ (Národní muzeum P1N 47856, ex coll. J. Ryš). Foto: D. Velebil. 